\title{
Tropospheric ozone: respiratory effects and Australian air quality goals
}

Alistair Woodward, Charles Guest, Kelvyn Steer, Andrew Harman, Raffaele Scicchitano, Dino Pisaniello, Ian Calder, Anthony McMichael

Department of Community Medicine, University of Adelaide South Australia 5005

A Woodward

C Guest

D Pisaniello

A McMichael

Office of the Environment Protection Authority, Department of Environment and Natural Resources, South Australia K Steer

Department of Pharmacology, University of Western Australia A Harman

Department of Thoracic Medicine, Royal Adelaide Hospital,

South Australia

R Scicchitano

Environmental Health Branch, Public and Environmental Health Service, South Australian Health Commission I Calder

Correspondence to: Dr A Woodward, Department of Public Health, Wellington School of Medicine, University of Otago, PO Box 7343 Wellington, New Zealand.

Accepted for publication February 1995

\section{Abstract}

Objective - To review the health effects of tropospheric ozone and discuss the implications for public health policy.

Design - Literature review and consultation with scientists in Australia and overseas. Papers in English or with English language abstracts were identified by Medline search from the international peer reviewed published reports. Those from the period 1980-93 were read systematically but selected earlier papers were also considered. Reports on ozone exposures were obtained from environmental agencies in the region.

Results - Exposure to ozone at concentrations below the current Australian air quality goal (0.12 ppm averaged over one hour) may cause impaired respiratory function. Inflammatory changes in the small airways and respiratory symptoms result from moderate to heavy exercise in the presence of ozone at levels of $0.08-0.12 \mathrm{ppm}$. The changes in respiratory function due to ozone are short lived, vary with the duration of exposure, may be modified by levels of other pollutants (such as sulphur dioxide and particulates), and differ appreciably between individuals. Bronchial lavage studies indicate that inflammation and other pathological changes may occur in the airways before reductions in air flow are detectable, and persist after respiratory function has returned to normal. It is not known whether exposures to ozone at low levels $(0 \cdot 08-0.12 \mathrm{ppm})$ cause lasting damage to the lung or, if such damage does occur, whether it is functionally significant. At present, it is not possible to identify confidently population subgroups with heightened susceptibility to ozone. People with asthma may be more susceptible to the effects of ozone than the general population but the evidence is not consistent. Recent reports suggest that ozone increases airway reactivity on subsequent challenge with allergens and other irritants. Animal studies are consistent with the findings in human populations.

Conclusion - A new one hour air quality ozone goal of $0.08 \mathrm{ppm}$ for Australia, and the introduction of a four hour goal of $0.06 \mathrm{ppm}$ are recommended on health grounds.

(f Epidemiol Community Health 1995;49:401-407)
Ozone $\left(\mathrm{O}_{3}\right)$ is a strong oxidant and respiratory irritant. Ozone in the troposphere, the lowest layer of the atmosphere, extending to $10-20 \mathrm{~km}$ above the earth's surface, is formed principally by the action of sunlight on nitrogen oxides $\left(\mathrm{NO}_{x}\right)$, in the presence of reactive organic compounds (ROC). In urban areas $\mathrm{NO}_{\mathrm{x}}$ and $\mathrm{ROC}$ are generated largely by motor vehicles and industrial activities that burn fossil fuels. In Australia background levels of ozone range from $0-0.03 \mathrm{ppm}$. Much higher levels (in the range $0 \cdot 1-0.4 \mathrm{ppm}$ ) occur when photochemical "smog" forms. This is a complex mixture in which nitrogen dioxide $\left(\mathrm{NO}_{2}\right)$ and oxygen $\left(\mathrm{O}_{2}\right)$ react in the presence of sunlight and $\mathrm{ROC}$, to form $\mathrm{O}_{3}$ and other oxidant species. In the future, population growth, increased motor vehicle traffic and expanding industrial activity will increase the emissions of the precursors of ozone, and lead possibly to more widespread pollution with photochemical oxidants.

Internationally, air quality goals for ozone averaged over one hour range from $0.06 \mathrm{ppm}$ (Japan) to $0 \cdot 12 \mathrm{ppm}$ (United States - currently under review). The World Health Organization proposes a one hour air quality goal between $0.076 \mathrm{ppm}$ and $0.1 \mathrm{ppm} .{ }^{1}$ In California, where some of the heaviest photochemical oxidant pollution in the world has occurred, the one hour air quality goal for ozone is $0.09 \mathrm{ppm}$. $^{2}$ The current Australian air quality goal for ozone $(0.12 \mathrm{ppm}$ averaged over one hour) was last revised in 1985-6. Since then many new studies on the health effects of ozone have been reported, and it is timely to reconsider the scientific basis for the goal.

\section{Human health effects}

SYMPTOMS AND LUNG FUNCTION

Symptoms that have been associated with ozone exposure in the urban setting including cough, throat dryness, increased mucus production, wheeze, chest pain or tightness, lassitude, malaise, and nausea. ${ }^{3-5}$ Chamber studies have reported similar findings, although the exposures required to induce symptoms have been higher than those described in field studies. ${ }^{67}$

The most comprehensive information on ozone and lung function in a natural setting comes from studies of children, many of which were conducted at summer camps in North America. ${ }^{8}$ In these studies multiple measurements of pulmonary function and concurrent levels of ozone and other air pollutants were made over several weeks. The findings 
Table 1 Changes in respiratory function associated with ozone: field studies*

\begin{tabular}{lllll}
\hline $\begin{array}{l}\text { No of } \\
\text { subjects }\end{array}$ & $\begin{array}{l}\text { Age range } \\
(y)\end{array}$ & $\begin{array}{l}\text { Maximum ozone } \\
\text { concentration }(p p m)\end{array}$ & $\begin{array}{l}\text { Change in FEV } \\
\text { (Mean, l/ppm } O_{3} \text { ) }\end{array}$ & Reference \\
\hline 58 & $8-13$ & $0 \cdot 11$ & $-0 \cdot 78$ & Lippmann $^{64}$ \\
39 & $7-12$ & $0 \cdot 19$ & $-0 \cdot 28$ (NS) & Lioy $^{65}$ \\
24 & $8-33$ & $0 \cdot 16$ & $-0 \cdot 6$ & Linn $^{66}$ \\
91 & $8-15$ & $0 \cdot 12$ & $-1 \cdot 4$ & Spektor $^{16}$ \\
$30 \dagger$ & $27-39$ & $0 \cdot 12$ & $-1 \cdot 4$ & Spektor $^{67}$ \\
$154 \ddagger$ & $10-12$ & $0 \cdot 08$ & -0.999 & Kinney $^{9}$ \\
43 & $7-13$ & $0 \cdot 25$ & -0.39 & Higgins $^{68}$ \\
46 & $8-14$ & $0 \cdot 10$ & $-1 \cdot 6$ & Spektor $^{69}$ \\
5530 & $7-11$ & $0 \cdot 12$ & -0.42 & Hoek $^{70}$ \\
\hline
\end{tabular}

* Summer camp studies, conducted in rural areas of US, except for toutdoor exercise periods, duration $0 \cdot 25-1 \mathrm{~h}$;

† outdoor exercise periods, duration late winter, early spring;

f school, late winter, early spring;

If $\mathrm{FEV}_{0.75}$

NS not statistically significant $(p>0.05)$. All other reductions in FEV, were significant $(p<0.05)$.

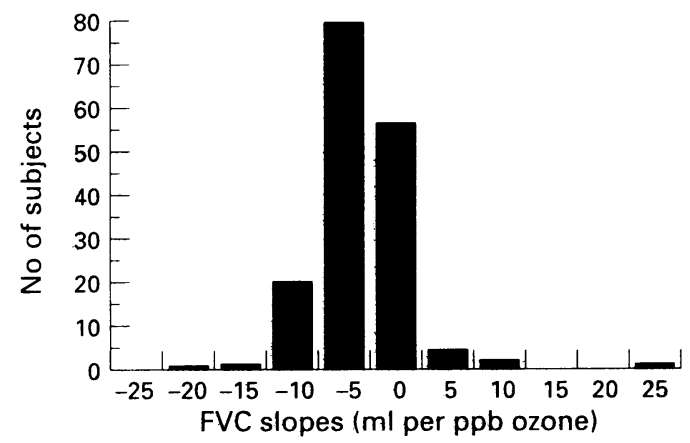

Short term pulmonary function change associated with ozone. Results of regression of forced vital capacity (FVC) on ozone concentration, 154 children. Data from Kinney

are summarised in table 1 , where the effect of ozone is displayed as the mean fall in forced expiratory volume in one second $\left(\mathrm{FEV}_{1}\right)$ for a unit increase in ozone concentration (measured as parts per million (ppm) averaged over one hour). In all these studies the responses of individual children to ozone varied widely, as shown by Kinney (figure). ${ }^{9}$

Controlled exposure studies carried out with volunteers in chambers show that short term exposures (less than one hour) to ozone concentrations greater than $0.12 \mathrm{ppm}$ lead to reductions in $\mathrm{FEV}_{1}$ of up to $10 \%$ (table 2). Studies which have reported effects on respiratory function at ozone levels less than $0 \cdot 12 \mathrm{ppm}$ have generally employed exposures exceeding 1-2 hours, in conjunction with moderate to heavy levels of exercise. ${ }^{1011} \mathrm{McD}$ onnell $^{12}$ reported a mean decline in $\mathrm{FEV}_{1}$ of more than $8 \%$ after $0.08 \mathrm{ppm}$ ozone for 6.6 hours. Extrapolation of these data at an eight hour work day of heavy manual labour suggests that ozone concentrations of $0.08,0 \cdot 10$, and

Table 2 Changes in respiratory function associated with ozone: chamber studies of healthy adults

\begin{tabular}{|c|c|c|c|c|c|}
\hline $\begin{array}{l}\text { No of } \\
\text { subjects }\end{array}$ & $\begin{array}{l}\text { Age range } \\
\text { (y) }\end{array}$ & $\begin{array}{l}\text { Maximum ozone } \\
\text { concentration }(p p m)\end{array}$ & $\begin{array}{l}\text { Duration } \\
\text { (h) }\end{array}$ & $\begin{array}{l}\text { Change in } F E V_{1} \\
\text { (mean, } l_{p p m ~} O_{3} \text { ) }\end{array}$ & Reference \\
\hline $\begin{array}{l}22 \\
20 \\
50 \\
10 \\
20 \\
30 \\
10\end{array}$ & $\begin{array}{l}19-25 \\
20-26 \\
19-32 \\
20-26 \\
21-29 \\
27-39 \\
18-33\end{array}$ & $\begin{array}{l}0.12 \\
0.18 \\
0.16 \\
0.15 \\
0.25 \\
0.12 \\
0.12 \\
0.08 \\
0.10 \\
0.12\end{array}$ & $\begin{array}{l}2 \\
2 \\
1 \\
2 \\
2 \\
0 \cdot 5 \\
6 \cdot 6 \\
6 \cdot 6 \\
6 \cdot 6 \\
6 \cdot 6\end{array}$ & $\begin{array}{l}-1.3 \\
-1.6 \\
-1.3 \\
-1.1 \\
-1.3 \\
-1.4 \\
-4.5 \\
-3.9 \\
-3.0 \\
-4.5\end{array}$ & $\begin{array}{l}\text { McDonnell } \\
\text { McDonnell }^{6} \\
\text { Avol }^{43} \\
\text { Gibbons }^{71} \\
\text { Kulle }^{72} \\
\text { Spektor }^{67} \\
\text { Folinsbee }^{10} \\
\text { Horstman }^{11}\end{array}$ \\
\hline
\end{tabular}

$0 \cdot 12 \mathrm{ppm}$ would decrease $\mathrm{FEV}_{1}$ by 9,15 , and $20 \%$ respectively. ${ }^{13}$

The chamber studies also show large intersubject variability in the magnitude of responses, although individual ozone responsiveness is moderately reproducible. ${ }^{14}$ With longer exposures, effects are observed at lower ozone concentrations, indicating that both peak exposure and cumulative exposure may be important determinants of the lung response. ${ }^{13}$ Most expired spirometric variables are strongly correlated, suggesting that there is a common functional impairment, probably a restriction of inspiration.

The dose-response relationship between ozone exposure and respiratory impairment varies with the level of activity, duration of exposure, and individual susceptibility. In one controlled exposure study, the changes in FEV and forced vital capacity (FVC) increased threefold between light and very heavy exercise for the same change in ozone concentration..$^{15}$ In the same study a mean $5 \%$ fall in $\mathrm{FEV}_{1}$ was produced by $0.29 \mathrm{ppm}$ ozone over one hour with moderate exercise, but by only $0.07 \mathrm{ppm}$ when exposure was for 6.6 hours. Within the range of the laboratory data, there seems to be a linear or curvilinear relation between ozone exposure and reduction in respiratory function. ${ }^{10}$ It is not known whether, at lower concentrations, there is a threshold level below which respiratory function is unaffected by changes in exposure to ozone.

As with symptoms, the respiratory effects on lung function reported in field studies tend to be greater than would be expected on the basis of the chamber experiments alone. ${ }^{16-18}$ It may be that the effect of ozone on the lung is amplified by the presence of other air pollutants such as acid particulates and $\mathrm{NO}_{2}$. However, chamber experiments have not shown this to occur with $\mathrm{NO}_{2}{ }^{19}$ or sulphuric acid. ${ }^{20}$ Another possibility is that the ozone levels recorded in field studies systematically underestimate personal exposures. There is some evidence that individual doses recorded by personal monitors tend to exceed estimates from stationary monitors. ${ }^{21}$

Spirometric tests are relatively insensitive guides to the existence of pathology in the airways. Bronchial lavage studies show that inflammation in the walls of the small airways occurs after exposure to ozone levels of $0 \cdot 08-0 \cdot 12 \mathrm{ppm}$ over six hours (with moderate exercise), and this inflammation may be observed up to 18 hours after respiratory function has returned to pre-exposure levels..$^{22}$ The clinical importance of such changes in the small airways is not known.

\section{ASTHMA}

In Australia in recent decades there has been a concurrent rise in mortality from asthma ${ }^{23}$ and output of vehicle emissions and other ozone precursors. There is little information, however, relating ozone to the incidence of asthma, in Australia or overseas. In the United States six cities study ${ }^{24}$ of $10-12$ year old children, particulates were associated more strongly than 
ozone with bronchitis, chronic cough, and chest illness, while ozone was the only measured pollutant associated with asthma. Holguin ${ }^{25}$ studied 42 non-smokers, with stable, well defined asthma but no other pulmonary disease, during periods of high photochemical oxidant pollution. this is one of the most informative studies of asthma that is available, since it includes measurements of exposure and disease for individuals. Ambient levels of ozone, nitrogen dioxide, pollen, temperature, and relative humidity were determined by air monitoring stations located near the dwellings of all subjects. The average ozone level in the 12 hour study periods was less than $0.05 \mathrm{ppm}$ in all instances; the maximum 12 hour ozone exposure was less than $0.12 \mathrm{ppm}$ for 39 of the 42 subjects. Asthma was more common at higher ozone levels: the probability of an episode increased by 0.025 for an increase of $0.04 \mathrm{ppm}$ ozone.

There is some evidence that ambient ozone levels may be weakly related to the occurrence of severe asthma resulting in hospital admission. ${ }^{2627} \mathrm{~A}$ recent study in Melbourne, however, ${ }^{28}$ reported that "ozone days", defined by a one hour ozone value $\geq 0.09 \mathrm{ppm}$, were not associated with the frequency of hospital presentations for childhood asthma.

Non-specific bronchial responsiveness is increased by exposure to ozone. Horstman ${ }^{11}$ exposed healthy volunteers to graded levels of ozone for 6.6 hours with exercise and found that the dose of methacholine which increased airways resistance by $100 \%$ decreased with higher levels of ozone. Folinsbee ${ }^{10}$ reported that airway reactivity to inhaled methacholine was approximately doubled after exposure to $0 \cdot 12 \mathrm{ppm}$ ozone with exercise over 6.6 hours. Moreover, changes in non-specific bronchial hyper-responsiveness induced by ozone may predispose individuals to bronchospasm from other environmental agents such as $\mathrm{SO}_{2}{ }^{29}$ or allergens. $^{30}$

\section{OTHER RESPIRATORY ILLNESSES}

There is no consistent evidence linking ozone with respiratory illnesses other than asthma. The Ontario air pollution study showed that hospital admissions due to all respiratory illness were $7 \%$ greater on "high ozone days" $(0.08-0.2 \mathrm{ppm})$ than on "low ozone days" $(0.01-0.06 \mathrm{ppm}){ }^{31}$ The authors noted unusual peaks of acid aerosol of small particle size in this region in the summer, concomitant with raised ozone and sulphate levels. This increase in hospital admissions was interpreted cautiously as an "acid summer haze effect", rather than an effect of ozone specifically.

There are no epidemiological data on respiratory infections and ozone. Chamber studies have shown, however, that low levels of ozone have the potential to impair immune defence mechanisms. For example, Devlin ${ }^{22}$ exposed volunteers to 0.08 or $0.1 \mathrm{ppm}$ for 6.6 hours with moderate exercise $(40 \mathrm{l} / \mathrm{min})$ and reported that alveolar macrophages obtained by lavage had a decreased ability to phagocytise yeast via the complement receptor.
LONG TERM EFFECTS

Recovery of respiratory function after a single exposure to ozone generally occurs within 48 hours although some residual effects may persist for days. ${ }^{32}$ In laboratory studies, repeated exposures lead to progressively smaller decreases in respiratory function for a standard level of ozone. ${ }^{33}$ In people, long term exposures to ambient ozone seem to produce a functional adaptation which persists for several months. ${ }^{8}$ This does not imply tolerance - children in Mexico City who are exposed frequently to high levels of ozone still experience acute ozone-related decrements in lung function when they exercise. ${ }^{34}$

There is little information on the long term effects of ozone on the lung. Detels ${ }^{35}$ measured respiratory function of adult never-smokers in two communities in Los Angeles on two occasions, approximately five years apart. In one community, moderate levels of photochemical pollution (mean of 12 month peak hourly values, $1971-82,0.07 \mathrm{ppm}$ ) and low levels of other pollutants were recorded, compared with high levels of photochemical oxidant (mean $0 \cdot 11 \mathrm{ppm}$ ) and relatively high levels of sulphates and particulates in the other setting. A greater decline in respiratory function was observed in the high oxidant setting, but it is not clear how much of this effect should be attributed to ozone rather than other air pollutants. A subsequent paper from the same authors reported more rapid declines in respiratory function in a third community, exposed to high levels of $\mathrm{SO}_{2}$ and $\mathrm{NO}_{2}$ but relatively low levels of ozone (mean 1971-82, 0.04 ppm) than in the community with moderate photochemical pollution and low levels of other pollutants. ${ }^{36}$

\section{MORTALITY STUDIES}

A study of Los Angeles death records reported that all cause mortality on a given day was correlated with the maximum oxidant concentration on the previous day. ${ }^{37} \mathrm{~A}$ regression model with three variables $\left(\mathrm{NO}_{2}\right.$, one day lagged oxidant, and temperature) explained $4 \%$ of the short term variation in total mortality. Similar findings were obtained from an analysis of New York mortality data, 1971-76. ${ }^{38}$ In one of the most heavily polluted European cities, Athens, peak levels of air pollution $\left(\mathrm{SO}_{2}\right.$, ozone and smoke) were associated consistently with a small rise in overall mortality and this association was stronger on days with high temperatures. ${ }^{39}$

Thus, there does seem to be a small, but consistent, association between ozone and daily mortality in some large cities. The increase is small as a fraction of all deaths, and it is difficult to separate the possible effects of ozone from those of other air pollutants.

\section{SUSCEPTIBLE GROUPS}

The variability in individual response to ozone is unrelated to the individual's non-specific airway responsiveness or baseline $\mathrm{FEV}_{1} .^{1140}$ Smokers may be less sensitive, at least at 
concentrations of ozone equivalent to environmental exposure. ${ }^{4142}$ The lung function response to ozone is modified little by age, but it has been noted that children express symptoms due to ozone less readily than do adults. ${ }^{143}$ From the limited data available, it seems that functional responses caused by ozone in the elderly may be less than those in young adults. ${ }^{445}$ This may partly reflect reduced physical activity and lower ventilation rates of the elderly, and also lung "stiffening" with age.

It is uncertain whether people with asthma are more susceptible to the effects of ozone, although several recent papers report greater falls in respiratory function after exposure to ozone in those with a history of asthma. ${ }^{77} \mathrm{On}$ the basis of a small number of studies, there is no evidence of a marked susceptibility to ozone in people with other major respiratory diseases. ${ }^{4647}$

Heavy exercise lowers the concentration of ozone at which respiratory effects become apparent and increases the severity of effects, presumably due to the increased dose received by the lung at high levels of ventilation. Athletic performance may be impaired at peak ozone levels around $0 \cdot 12 \mathrm{ppm} .{ }^{48}$ Dose dependent effects are apparent at levels down to $0.08 \mathrm{ppm}$ (over $6 \cdot 6$ hours). ${ }^{11}$

\section{Animal studies}

Animal studies suggest that there is no threshold dose for some of the toxic effects of ozone, ${ }^{4950}$ but little is known about the effects of doses equivalent to those received by humans when ozone concentrations are in the range $0 \cdot 08-0 \cdot 12 \mathrm{ppm}$. In principle, toxicity will occur when the rate of interaction of ozone with its target tissue (or toxicological receptor) exceeds the ability of antioxidant mechanisms to repair that damage. Neither the key toxic events nor the role of the antioxidant mechanisms in these events, however, are well understood at present.

Studies of monkeys exposed to relatively high levels of ozone $(>0.25 \mathrm{ppm})$ suggest that intermittent exposures may produce greater effects than those produced by a continuous exposure regimen, even though the latter results in a higher cumulative dose. ${ }^{51}$ This is consistent with findings of controlled exposure studies in humans $\mathrm{s}^{52}$ and suggests that damage results, at least in part, from the repeated attempts to adapt to the irritant challenge as well as to the direct effects of the irritant exposure.

Exposure of animals to ozone on successive days leads to an attenuation of the decrement of lung function. The biological importance of this functional adaptation is not known. Some studies have shown that persistent damage to lung cells may occur at the same time as so called "adaptative" changes in respiratory function. ${ }^{53}$ It has yet to be determined if adaptation is a means of protecting from ozone toxicity with prolonged exposure. An alternate hypothesis is that the tissue is no longer responding to the stimulus provided by the ozone insult because of structural or functional damage.
Little is known about the effects of ozone on lung development in early life. Generally, the lungs of neonatal animals are more resistant to ozone that those of older animals. ${ }^{54}$ However, the influence of animal age on response to ozone depends upon the particular response that is studied. ${ }^{55}$

Animal experiments have shown interactions between ozone and other air pollutants. For example, a study of allergen sensitivity in mice noted synergistic effects between ozone and sulphuric acid. ${ }^{56}$ In rats, synergism has been noted between $\mathrm{O}_{3}$ and $\mathrm{NO}_{2}$, using parameters such as lung weight and detoxification enzyme activities, ${ }^{57}$ or lung lavage protein as an index of damage. ${ }^{58}$ These interactive effects have been observed, in animals, at levels of pollutants equivalent to those found in the ambient atmosphere..$^{590}$

The limited data available suggest humans are more sensitive to the effects of ozone than the most commonly studied laboratory animal, the rat. ${ }^{8}$ For example, rats exposed to $0.5 \mathrm{ppm}$ ozone for 6.6 hours $^{61}$ had functional decrements similar to those seen in humans exposed to $0.12 \mathrm{ppm}$ for the same time. ${ }^{52} \mathrm{It}$ is not known whether this difference in sensitivity extends to other ozone induced effects (for example, inflammatory responses).

\section{Implications for public health}

There are many uncertainties surrounding the estimation of the health effects of ozone. In most instances human studies rely on indirect measures of the effective dose to the lung. Personal exposures are frequently estimated from measurement of ambient ozone at a small number of test sites, although it is well known that ozone levels may vary greatly over a small area depending on air flows and local scavenging. In field studies, individual doses are also influenced by factors such as the time spent outdoors, physical activity patterns, and ventilation rates. The consequences of these uncertainties in measurement of the dose of ozone are not predictable, although in the absence of systematic error, the effects of ozone will generally be underestimated.

In natural settings ozone always occurs in association with other pollutants. These pollutants may themselves cause illness and respiratory impairment, and it is frequently difficult in epidemiological studies to control confounding by factors such as $\mathrm{NO}_{2}$ and particulates. A separate issue is that of interaction or effect modification. The effect of ozone on the respiratory tract may be amplified when exposure occurs in conjunction with other agents such as $\mathrm{SO}_{2}$. Interactions of this kind complicate risk assessments, and indeed from the point of view of health policy it would be preferable to frame standards in terms of commonly-encountered mixtures or combinations of pollutants (such as the total of ozone and $\mathrm{NO}_{2}$ ).

The objective of air quality guidelines is to set levels of air pollution which will avoid, or minimise, adverse health effects. There is contention over whether the changes that are 
observed after exposure to ozone in the range $0.08 \mathrm{ppm}$ to $0.12 \mathrm{ppm}$ should be described as adverse health effects. For example, it may be argued that the loss of lung function that follows exposure to low levels of ozone $(\leq 0 \cdot 12 \mathrm{ppm})$ is reversible, is not disabling, and is not known to cause harm in the long term, and therefore should not be labelled as an "adverse" health effect. Another view, which we support, is that any impairment of lung function is by definition an adverse effect on health, especially when the range of individual responses is very wide, and the effect of exposure (to ozone) may be increased by the presence of other pollutants.

There remains considerable uncertainty about the long term effects of low levels of ozone on human health. Animal studies show possible mechanisms by which ozone may cause irreversible damage to the lung, although fibrosis and serious lung disease have not been observed after chronic exposures, even at high levels. Studies in human populations show greater declines in respiratory function with time in communities with high ozone levels, but it remains unclear how much this is due to ozone and not to other, coexisting pollutants, and the functional significance of the observed effect is not known. There are no data from prospective studies of children linking ozone and lung function, and therefore it is not known whether ozone at levels around $0.12 \mathrm{ppm}$ affects lung growth in children.

\section{IMPACT OF TROPOSPHERIC OZONE ON HEALTH IN AUSTRALIA}

Australian cities vary widely in the magnitude of their problems with photochemical pollution. Over the last decade Melbourne and Sydney have often experienced ozone levels exceeding the current NHMRC one hour guideline of $0.12 \mathrm{ppm}$. (Ozone levels are measured less comprehensively in other Australian cities. From the available data it seems likely that concentrations about $0.12 \mathrm{ppm}$ rarely occur outside Melbourne and Sydney). The factors that influence ozone levels include population size, area of settlement, motor vehicle use, industrial activity, and topography and weather patterns unique to each city. The relative importance of these factors is not well understood. Despite considerable urban growth in the last decade, in Sydney the number of days each year on which the air quality goal for ozone was exceeded has tended to fall. New South Wales Environment Protection Agency, unpublished data).

The variability in annual exceedances shows the very strong effect of weather on concentrations of pollutants in the urban atmosphere. While source strengths define potential maxima, sunlight, weather conditions, including wind speed and direction, inversion heights and circulation patterns over a city will determine whether concentrations will actually achieve that potential.

What would be the savings in Australia, in health terms, if the air quality goal for ozone were lowered? The number of people in Australia exposed each year to levels of ozone around the current air quality goal of $0 \cdot 12 \mathrm{ppm}$ in one hour is unknown, but is likely to be very large. For example, in Melbourne it is estimated that between 1982 and 1990 approximately 16 exceedances per annum would occur if a goal of $0.08 \mathrm{ppm}$ were introduced in place of $0 \cdot 12 \mathrm{ppm}^{62}$ Typical exceedances occur over areas that may include about $10 \%$ of the surface area of the Melbourne statistical division (total population 3 million). The number of people exposed on each occasion when the monitored level of ozone exceeds $0.08 \mathrm{ppm}$ depends on many factors, including population density and activity patterns (such as time spent outdoors), and therefore no precise estimate can be made. However it seems likely that several hundred thousand people in Melbourne are exposed each year on at least one occasion to levels of ozone between 0.08 and $0.12 \mathrm{ppm}$, averaged over one hour. In Sydney, the numbers exposed to such levels of ozone may be greater still. Between 1990 and 1992, the number of hours per year when levels of $0.08 \mathrm{ppm}$ and higher were recorded in Sydney was 60, compared with 16 in Melbourne. (S McPhail, personal communication).

Exceedances between 0.08 and $0.12 \mathrm{ppm}$ are unlikely to cause respiratory embarrassment for most of the population. Some susceptible individuals will experience a temporary loss of function amounting to $10 \%$ or more of $\mathrm{FEV}_{1}$, which may be disabling, although the number of these people is not known. Persons undertaking heavy physical activity out of doors during the period when ozone levels are between 0.08 and $0.12 \mathrm{ppm}$ are likely to experience symptoms (such as cough, throat dryness) and reduced peak athletic performance.

Some people with asthma are likely to experience additional asthma attacks as a consequence of exposure to ozone at 0.08 to $0.12 \mathrm{ppm}$, either directly from irritant effects of ozone or due to sensitisation to subsequent allergens, but it is not known at present how many attacks of asthma may be attributed to ozone. Asthma is common in Australia, affecting approximately $10 \%$ of adults ${ }^{63}$ and $20-25 \%$ of children. ${ }^{23}$ Therefore a small increase in risk of an asthma attack for an individual represents a substantial additional burden of illness, nationally, as a consequence of widespread exposure to increased ozone levels.

\section{Conclusions}

In our judgement, there is firm evidence that exposure to ozone at around $0.12 \mathrm{ppm}$ over one hour may lead to a reduction in respiratory function, inflammatory changes in the lung, and increased reactivity of airways. The changes are small, on average, but there is a wide range of individual susceptibility. Little is known about the effects of chronic exposures on health because few good studies have been carried out, but animal studies indicate that exposure to ozone may cause long term damage to the lung. The number of people who may be exposed to high levels of ozone is large and, currently, there is no margin of safety between 
the goal and the level at which adverse health effects are observed.

We recommend a one hour goal of $0.08 \mathrm{pp}$. This is not a "no effect" level - the current evidence suggests that more sensitive measurements of lung function than are currently available will show deleterious effects of ozone at levels down to, and perhaps including, background. At present, reductions in respiratory function have been observed at $0.08 \mathrm{ppm}$ but only in the presence of heavy exercise sustained for two hours or longer.

We also recommend a new four hour goal of $0.06 \mathrm{ppm}$. The reasons for this are that the effects of ozone on pulmonary function accumulate over several hours, ${ }^{911}$ and raised ozone levels in towns are typically spread over a period of 3-6 hours. We suggest that the averaging time for a second goal should be set at four hours. To avoid health effects, the published reports suggest that this level should be lower than $0.08 \mathrm{ppm}$, and we propose a figure that lies approximately midway between the level that is currently known to induce health effects and background.

A four hour goal may be less stringent that a one hour goal, if there are short lived peaks in ambient ozone levels. At present, for example, fewer exceedances of the $0.08 \mathrm{ppm}$ level, averaged over four hours, are recorded in Sydney than exceedances of the current objective $(0.12 \mathrm{ppm}$, measured over one hour). We recommend that a one hour goal be retained to control peak exposures (and to maintain a consistent index of air quality) in addition to the four hour goal.

The margin between the air quality goal for ozone and background levels is not wide, and would be approximately halved by reducing the one hour goal from 0.12 to $0.08 \mathrm{ppm}$. As the goal approaches background the cost of controlling emissions will increase sharply, and at some point it is expected that society will judge that the cost of further improvement in air quality is too great to be borne. Social judgements must be made about acceptable costs and tolerable detriment to health. The next step is to explore the social, economic and environmental consequences of adopting and enforcing more stringent air quality goals for ozone.

This paper is based on a report prepared for and funded by the National Health and Medical Research Council. Many scientists in Australia, and overseas, participated in the consultative proin Australia, and overseas, participated in the consultative proof this paper. We gratefully acknowledge their assistance.

1 World Health Organization. Air quality guidelines for Europe. Copenhagen: World Health Organization European Office, 1987 .

2 Chock DP. Issues regarding the ozone air quality standards. fourmal of the Air Waste Management Association 1991;241: 148-52.

3 Holtzman MI. Effects of ozone on bronchial reactivity in atopic and nonatopic subjects. Am Rev Respir Dis 1979; 120:1059-67.

4 Schwartz J. Air pollution and the duration of acute respiratory symptoms. Arch Environ Health 1992;47:116-22.

5 Ostro BD, Lipsett MJ, Mann JK, Krupnick A, Harrington W. Air pollution and respiratory morbidity among adults in W. Air pollution and respiratory morbidity among adults in

6 McDonnell WE, Horstman DH, Hazucha MJ, et al. Pulmonary effects of ozone exposure during exercise: Dosemonary effects of ozone exposure during exercise: Dose-

7 Kreit JW, Gross KB, Moore TB, Lorenzen TJ, D'Arcy J, Eschenbacher IWL. Ozone-induced changes in pulmonary function and bronchial responsiveness in asthmatics. $f$ Appl Physiol 1989;66:217-22.
8 Lippmann M. Effective strategies for population studies of acute air pollution health effects. Environ Health Prospect 1989;81:115-9.

9 Kinney PL, Ware JH, Spengler JD, Dockery DW, Speize FE, Ferris Jr BG. Short-term pulmonary function change in association with ozone levels. Am Rev Respir Dis 1989; 139:56-61.

10 Folinsbee LJ, McDonnell WF, Horstman DH. Pulmonary function and symptom responses after $6 \cdot 6$-hour exposure function and symptom responses after $6 \cdot 6$-hour exposure
to $0.12 \mathrm{ppm}$ ozone with moderate exercise. Fournal of the Air Pollution Control Association 1988;38:28-35.

11 Horstman DH, Folinsbee LJ, Ives PJ, Abdul-Salaam S, McDonnell WF. Ozone concentration and pulmonary response relationships for 6.6-hour exposures with five hours of moderate exercise to $0.08,0 \cdot 10$, and $0.12 \mathrm{ppm}$ Am Rev Respir Dis 1990;142:1158-63.

12 McDonnell WF, Kehrl HR, Abdul Salaam S et al. Respiratory response of humans exposed to low levels ozone for 6.6 hours. Arch Envinon Health 1991;46:145-50.

13 Larsen RI, McDonnell WF, Horstman DH, Folinsbee L An air quality data analysis system for interrelating effects, standards, and needed source reductions. Part ii. A los, normal model relating human lung function decrease to exposure. Fournal of the Air Waste Management Association 1991; 41:455-9.

14 McDonnell WF, Chapman RS, Leigh MW, Strope GI Collier AM. Respiratory responses of vigorously exercisin Collier AM. Respiratory responses of vigorously exercising
children to $0 \cdot 12 \mathrm{ppm}$ ozone exposure. Am Rev Respir Dis children to $0 \cdot 12 \mathrm{p}$

15 Hazucha MJ. Relationship between ozone exposure and pulmonary function changes. F Appl Physiol 1987;62:1671 80.

16 Spektor DM, Lippmann M, Thurston GD et al. Effects of ambient ozone on respiratory function in healthy adult exercising outdoors. Am Rev Respir Dis 1988;138:821-8.

17 Krzyzanowski M, Quackenboss JJ, Lebowitz MD. Relation of peak expiratory flow rates and symptoms to ambien ozone. Arch Environ Health 1992;47:107-15.

18 Lippmann $M$. Health effects of tropospheric ozone: review of recent research findings and their implications to ambient air quality standards. Fournal of Exposure and Analytic Environmental Epidemiology 1993;3:1-27.

19 Koenig JC, Covert DS, Marshall SG, van Belle G, Pierso WE. The effects of ozone and nitrogen dioxide on pulmonary function in healthy and asthmatic adolescents. Am Rev Resp Dis 1987;136:1152-7.

20 Stacy RW, Seal E, House DE, Green J, Roger LJ, Raggio L. A survey of effects of gaseous and aerosol pollutant on pulmonary function of normal males. Arch Environ Health 1983;38:104-15.

21 Liu L-JS, Koutrakis P, Suh HH, Mulik JD, Burton RM. Use of personal measurements for ozone exposure assessment: a pilot study. Environ Health Perspect 1993;101: 318-24.

22 Devlin RB, McDonnell WF, Mann R, et al. Exposure of humans to ambient levels of ozone for 6.6 hours causes cellular and biochemical changes in the lung. $A m \mathcal{F}$ Respir Cell Mol Biol 1991;4:72-81.

23 Robertson CF, Heycock E, Bishop J, Nolan T, Olinsky A Phelan PD. Prevalance of asthma in Melbourne schoolchildren: changes over 26 years. $B M \mathcal{F}^{\prime} 1991 ; 302: 1116-8$. 24 Dockery DW, Speizer FE, Stram DO, Ware JH, Spengler JD, Ferris Jr BG. Effects of inhalable particles on respiratory health of children. Am Rev Respir Dis 1989;139. 587-94.

25 Holguin AH, Buffler PA, Contant JR F, et al. The effects of ozone on asthmatics in the Houston area. In: Le SD, ed. Transactions of the APCA international specialty conference: Evaluation of the scientific basis of ozoneloxidan standards, Pittsburgh: Air Pollution Control Association, 1985:262-280.

26 Ponka A. Asthma and low level air pollution in Helsinki. Arch Environ Health 1991;46(5):262-70.

27 Schmitzberger R, Rhomberg K, Kemmler G. Chronic exposure to $0 z 0$ e and respiratory health of children [Letter]. Lancet 1992;339:881-2.

28 Rennick GJ, Jarman FC. Are children with asthma affected by smog? Med $\mathcal{f}$ Aust 1992;156:837-41.

29 Koenig JC, Covert DS, Hanley OS, van Belle G, Pierson WE. Prior exposure to ozone potentiates subsequent response to sulfur dioxide in adolescent asthmatic subjects. Am Rev Resp Dis 1990;141:377-80.

30 Molfino NA, Wright SC, Katz I et al. Effect of low concentrations of ozone on inhaled allegen responses in asthmatic subjects. Lancet 1991;338:199-203.

31 Bates DV, Sizto R. The Ontario Air Pollution Study: identification of the causative agent. Environ Health Perspect 1989;79:69-72.

32 Ostro BD. Examining acute health outcomes due to ozone exposure and their subsequent relationship to chronic disease outcomes. Cambridge MA: Health Effects Institute 1991.

33 Horvath SM, Gliner JA, Folinsbee LJ. Adaptation to ozone: Duration of effect. Am Rev Respir Dis 1981;123:496-9.

34 Castillejos M, Gold DR, Dockery D, Tosteson T, Baum $\mathrm{T}$, Speizer FE, Effects of ambient ozone on respiratory Am Rev Respir Dis 1992;145:A95.

35 Detels R, Tashkin DP, Sayre JW, et al. The UCLA population studies of chronic obstructive respiratory disease. Chest 1987;92:594-603.

36 Detels R, Tashkin DP, Sayre JW, et al. The UCLA population studies of CORD: X. A cohort study of changes in respiratory function association with chronic exposure to $\mathrm{SO}_{x}, \mathrm{NO}_{x}$, and hydrocarbons. Am $\mathcal{F}$ Public Health 1991; 81:350-9.
81, 
37 Kinney PL, Ozkaynak H. Associations of daily mortality and air-pollution in Los Angeles County. Environmental Research 1991;54:99-120.

38 Kinney PL, Ozkaynak H. Associations between ozone and daily mortality in Los Angeles and New York City. $A m$ Rev Resp Dis 1992;145:A94.

39 Katsouyanni K, Pantazopolou A, Toulomi G, et al. Evidence for interaction between air pollution and high temperature in the causation of excess mortality. Arch Environ Health in the causation

$40 \mathrm{McD}$ onnell WF. Determinants of acute ozone exposure. Am Rev Respir Dis 1990;141:A73.

41 Kagawa J. Exposure-effect relationship of selected pulmonary function measurements in subjects exposed to ozone. Int Arch Occup Environ Health 1984;53:345-58.

42 Emmons K, Foster WM. Smoking cessation and acute airway response to ozone. Arch Environ Health 1991;46: 288-95.

43 Avol EL, Linn WS, Shamoo DA, Valencia LM, Anzar UT, Hackney JD. Respiratory effects of photochemical oxidant air pollution in exercising adolescents. Am Rev Respir Dis 1985;132:619-22.

44 Drechsler-Parks DM, Dedi JF, Horvath SM. Pulmonary function responses of young and older adults to mixtures function responses of young and older adults to mixtures

45 Bedi JF, Horvath SM, Drechsler-Parks DM. Adaption by older individuals repeatedly exposed to 0.45 parts per
million ozone for two hours. Fournal of the Air Pollution million ozone for two hours. Fourna

46 Solic JJ, Hazucha MJ, Bromberg PA. The acute effects of $0.2 \mathrm{ppm}$ ozone in patients with chronic obstructive pulmonary disease. Am Rev Respir Dis 1982;125:664-9.

47 Linn WS, Medway DA, Anzar UT, et al. Persistence of adaptation to ozone in volunteers exposed repeatedly for six weeks. Am Rev Respir Dis 1982;125:491-5.

48 Schelegle ES, Adams WC. Reduced exercise time in competitive simulations consequent to low level ozone exposure. Med Sci Sports 1986;18:408-14.

49 Menzel DB, Wolpert RL. Is there a threshold for human health risk from ozone? In: Schneider T, Lee SD, Wolters GJR, Grant LD eds. Atmospheric ozone research and policy implications. Nijmegen, The Netherlands: Elsevier, policy 1989 .

50 Change L, Miller FJ, Ultman J, et al. Alveolar epithelial cell injuries by subchronic exposure to low concentrations of injuries by subchronic exposure to low concentrations of ozone correlate with cumulati

51 Hyde DM, Plopper CG, Harkema JR, St George JA, Tyler WR, Dungworth DL. Ozone-induced structural changes in monkey respiratory system. In: Schneider T, Lee SD, Wolters GJR, Grant LD eds. Atmospheric ozone research and its policy implications. Nijmegen, The Netherlands: Elsevier, 1989:398-400.

52 Hazucha MJ, Bates DV, Bromberg PA. Mechanism of action of ozone on the human lung. I Appl Physiol 1989;67: $1525-41$

53 Mustafa MG, Tierney DF. Biochemical and metabolic changes in the lung with oxygen, ozone and ntrogen dioxide. Am Rev Respir Dis 1978;118:1061-90.

54 Elsayed N, Mustafa MG, Postlethwiat EM. Age-dependent pulmonary response of rats to ozone exposure. $\not{7}$ Toxicol pulmonary response of rats to
Environ Health 1982;9:835-48.

55 Gunnison AF, Weideman PA, Sobo M, Koenig KL, Chen
LC. Age-dependence of responses to acute ozone exposure in rats. Fund Am Appl Toxicol 1992;18:360-9.

56 Osebold JW, Gerscgwub LJ, Zee YC. Studies on the enhancement of allergic lung sensitization by inhalation of zzone and sulfur acid aerosol. 7 Environ Pathol Toxicol 1980;3:221-34.

57 Lee JS, Mustafa MG, Afifi AA. Effects of short-term, single and combined exposure to low-level $\mathrm{NO}_{2}$ and $\mathrm{O}_{3}$ on lung tissue enzyme activities in rats. $₹$ Toxicol Environ Health tissue enzyme activit

58 Gelzleichter TR, Witschi H, Last JA. Concentration-response relationships of rat lung to exposure to oxidant air pollutants: a critical test of Haber's Law for ozone and nitrogen dioxide. Toxicol Appl Pharmacol 1992;112:73-80.

59 Last JA. Synergistic effects of air pollutants ozone plus a respirable aerosol. Res Rep Health Eff Inst 1991;38:1-32.

60 Sagai M, Ichinose T. Biochemical effects of combined gases of nitrogen dioxide and ozone. IV. Changes of lipid peroxidation and antioxidative protective systems in rat lungs upon life span exposure. Toxicology 1991;66:121-132.

61 Costa DL. Hatch GE, Highfill J, Stevens MA, Tepper JS. Pulmonary function studies in the rat addressing concentration versus time relationships of ozone. In: Schneider T, Lee SD, Wolters GJR, Grant LD, eds. Atmospheric ozone research and its policy implications. Nijmegen, The Netherlands: Elsevier, 1989.

62 Environment Protection Authority. Discussion paper on photochemical oxidants. Melbourne: Environment Protection Authority of Victoria, 191.

63 Peat JK, Haby M, Spijker J, Berry G, Woolcock AJ. Prevalence of asthma in adults in Busselton, Western Australia. BMF 1992;305:1326-9.

64 Lippmann M. Effects of ozone on the pulmonary function of children. Advances in Modern Environmental Toxicology 1983;5:423-46.

65 Lioy PJ, Vollmuth TA, Lippmann M. Persistence of peak flow decrement in children following ozone exposures exceeding the national ambient air quality standard. Fournal of the Air Pollution Control Association 1985;34: 1068-71.

66 Linn WS, Avol EL, Shamoo DA, et al A dose-response study of healthy, heavily exercising men exposed to ozone at concentrations near the ambient air quality standard. at concentrations near the ambie
Toxicol Ind Health 1986;2:99-112.

67 Spektor DM, Lippmann M, Lioy PJ, et al. Effects of ambient ozone on respiratory function in active normal children. Am Rev Respir Dis 1988;137:313-320.

68 Higgins IT, D'Arcy JB, Gibbons DI, Avol EL, Gross KB. Effect of exposures to ambient ozone on ventilatory lung function in children. Am Rev Respir Dis 1990;141:1136-46.

69 Spektor DM, Thurston GD, Mao J, He D, Hayes C, Lippmann $M$. Effects of single-and multi-day ozone exposures on respiratory function in active normal children. Environ Res 1991;55:107-22.

70 Hoek G, Fischer P, Brunekreef B, et al. Acute effects of ambient ozone on pulmonary function of children in the Netherlands. Am Rev Respir Dis 1993;147:111-17.

71 Gibbons SI, Adams WC. Combined effects of ozone exposure and ambient heat on exercising females. $\mathcal{F}$ Appl

72 Kulle TJ, Sauder LR, Hebel JR, Catham MD. Ozone response relationships in healthy non-smokers. Am Rev Respir Dis 1985;132:36-41. 